Queen's Dock is artificially warmed by sea water which passes through a nearby electrical power station, and the crab lives together with Carcinus maenas Leach among stones which are encrusted with such organisms as Balanus amphitrite Darwin, Hydroides norvegica (Gunnerus) and Mercierella enigmatica Fauvel. Shipping using the Dock consists mainly of oil tankers, some of which load in the eastern Mediterranean, and it seems likely that the crab has been transported by these vessels.

Wolff $^{2}$ records several examples of the transportation of erabs by ships, and those introduced to north-western European waters are Planes minutus Leach, Eriocheir sinensis Milne-Edwards, Pachygrapsus transversus Gibbes, Callinectes sepidus Rathburn and Rhithropanopeus harrisi Gould. Of these, Eriocheir sinensis has become established in several estuaries on the Continent, 3 , and Rhithropanopeus harrisi became established in the Zuider Zee (at least since 1876$)^{5}$ and in the South Harbour at Copenhagen ${ }^{2}$.

Examination of ships in dry dock suggests that hull fouling itself would be an unsuitable habitat for the transport of crabs, unless a vessel had been in harbour for a considerable length of time. Planes minutus may cling to fouling algae, but the species is often found among floating weed ${ }^{4}$, and it may occasionally reach the west coasts of Britain from North America among floating weed or timber ${ }^{6}$. In addition, occasional records of the American blue crab, Callinectes sepidus, in European waters may be accounted for in this way, or it may be transported in the ballast tanks of ships' ${ }^{2}$. Eriocheir sinensis was probably carried in ballast tanks ${ }^{3}$ and Rhithropanopeus harrisi may have been carried in the same manner ${ }^{2}$. Pachygrapsus transversus was found among external hull-fouling on a wooden ship in the harbour at Copenhagen, but the vessel had previously been docked for some time at Bermuda?

Brachynotus sexdentatus normally hides in crevices between stones, and it may be transported by sheltering beneath the grids which cover the sea inlet valves to the oil-storage tanks of tankers. Normal fouling seems inadequate to provide a foothold for Brachynotus, and shipping enters the Dock fully loaded and not in ballast. The lowest temperature recorded in the Dock during the winter of 1956-57 was about $14^{\circ} \mathrm{C}$. and salinity values never went below $30 \%$, so it appears that the crab could tolerate at least a summer voyage from the Mediterranean to British waters.

I am indebted to Mr. W. A. Morris, dock manager, for permission to carry out a faunistic survey of Swansea Docks and to Prof. E. W. Knight-Jones for much assistance. It is hoped to publish elsewhere descriptive notes on the specimens.

Department of Zoology,

E. NAYLOR

University College, Swansea.

May 6.

${ }^{1}$ Monod, Th., Mem. Inst. Franc. d'Afrique Noire, 45 (Dakar, 1956). ${ }^{2}$ Wolff, T., Nature, 174, 188 (1954).

${ }^{3}$ Peters, N., and Panning, A., Zool. Anz. Ergbd., 104, 1 (1933).

4 Bouvier, E.-L., Faune de France, 37 (Paris, 1940). 5 Buitendijk, A. M. , and Holthuis, L. B., Zool. Mededel. Leiden, 30, 95

"Bell, T. "A History of the British Stalk-eyed Crustacea" (London, 'Bertelson, F., and Ussing, H., Vidensk. Medd. Dank. Naturh. Foren.,
100, 237 (1936).

\section{Production of Carbon in the Sea}

The oxygen equivalent of the daily production of carbon in the North Sea, reported by D. H. Cushing ${ }^{1}$, ranges from 0.010 to 0.050 milligrams of oxygen per litre. These quantities, which could influence the saturation of a likely sea water to the extent of about 0.012-0.06 per cent, are much less than the 8-10 per cent supersaturation reported in different seas at the time of photosynthetic activity.

A plant growing in air can be enclosed for the study of photosynthesis without stimulating a bacterial flora which the enclosure of plants growing in a sea water always seems to do, with the risk of competition for a limited supply of nutrients. Under quiet sunny conditions, the inshore waters of the English Channel can become 50 per cent supersaturated with oxygen, as they did on several days in July 1955, with an oxygen production of some $1.7 \mathrm{mgm}$. per litre, equivalent to a round $650 \mathrm{mgm}$. of carbon per cubic metre on the scale used by Cushing. On April 13, 1957, at $8.45 \mathrm{hr}$., the sea was found to be 104 per cent saturated with oxygen. During the next seven hours, the oxygen content in the ambient sea rose by $1.79 \mathrm{mgm}$. per litre. Between $11.15 \mathrm{hr}$. and $13.20 \mathrm{hr}$., the oxygen rose by $0.94 \mathrm{mgm}$. per litre.

The carbon-14 technique for following the absorption of carbon dioxide is far more sensitive and elegant than the chemical estimation of oxygen, but it is suggested that some oxygen estimations should be made on the more active parts of the bulks of sea water from which the samples are taken for enclosure, in order to provide some certainty that the results are not only those of a laboratory exercise.

The Laboratory,

J. H. Oliver

Hayling Ferry,

Hayling Island,

Hants.

May 1.

'Cushing, D. H., Nature, 179, 876 (1957).

THE measurement of oxygen production for a short period using black and clear bottles to separate respiration from photosynthesis ${ }^{1}$ yields results in eutrophic waters similar to those using the carbon-14 technique, provided that the experiments do not last longer than $24 \mathrm{hr}^{2}$. My experiments lasted three hours, during which time bacterial effects will be small.

My results are similar to those of Steemann Nielsen off the mouth of the English Channel ${ }^{3}$ and are of the order expected from the yearly production of about $80 \mathrm{gm}$. carbon $/ \mathrm{m}^{2}$ from changes in phosphorus, nitrogen and carbon dioxide ${ }^{4}$. Dr. Oliver's observation of $10-20 \mathrm{gm}$. carbon $/ \mathrm{m}^{2}$ in seven hours in inshore waters is of considerable interest.

Fisheries Laboratory,

\section{H. Cushrng} Lowestoft.

${ }^{1}$ Gaarder, T., and Gran, H. H., Rapp. et Proc. Verb. Cons. Int. l'Exp. Mer., 42 (1927).

${ }^{2}$ Ryther, J. H., and Vaccaro, R. F., J. Cons. Int. Exp. Mer, 20, 25 (1954).

${ }^{3}$ Nielsen, E. Steemann, J. Cons. Int. Exp. Mer, 19, 309 (1954).

${ }^{4}$ Atkins, W. R. G., J. Mar. Biol. Assoc. U.K., 13, 3 (1923). 